\title{
A Note on Abbreviations, Citations, and Translations
}

Citations from Marx's works are from the editions listed here, using the abbreviations and formats described. Individual works by Marx and their citation format are included in the Chronology of Marx's Works, on pp. xvi-xviii.

German Editions of Marx's Works

MEGA 1975-. Marx-Engels Gesamtausgabe. Berlin: Dietz Verlag. Citations give the Abteilung (division) in Roman numerals and the Band (volume) in Arabic numerals, followed by the page number: (MEGA IV/1: 350). Nearly all volumes are accompanied by a separate Apparat with editorial notes and sources.

MEW 1956-68. Marx-Engels Werke. Berlin: Dietz Verlag. Citations give volume number and page number: (MEW 36 : 235).

English Editions of Marx's Works

C1 1976. Capital. Vol. 1, The Critique of Political Economy. Trans. Ben Fowkes. Introduction by Ernest Mandel. New York: Vintage Books.

C2 1981. Capital. Vol. 2, The Process of Circulation of Capital. Ed. Friedrich Engels. Trans. David Fernbach. Introduction by Ernest Mandel. New York: Vintage Books. 
$\mathrm{C}_{3}$ 1981. Capital. Vol. 3, The Process of Capitalist Production as a Whole. Ed. Friedrich Engels. Trans. David Fernbach. New York: Vintage Books.

CW 1975. Karl Marx and Frederick Engels Collected Works. New York: International Publishers.

Citations give volume number and page number: $\left(\mathrm{CW}_{2} 8\right.$ : 549).

EW 1975. Early Writings. Trans. Rodney Livingstone and Gregor Benton. Introduction by Lucio Coletti. New York: Vintage Books.

FIA 1974. The First International and After. Ed. with Introduction by David Fernbach. New York: Penguin Books.

R48 1973. The Revolution of 1848. Ed. with Introduction by David Fernbach. New York: Penguin Books.

SE 1973. Surveys from Exile. Ed. with Introduction by David Fernbach. New York: Penguin Books.

Citations from "Grundrisse" and from Marx's Letters

Karl Marx. 1973. Grundrisse. Trans. Martin Nicolaus. New York: Vintage Books.

Citations give the number of Marx's original notebook in Roman numerals I through VII or M (for the first notebook, which contains Marx's 1857 "Introduction"), followed by the page number of the English translation: (VII: 704). When the German text has also been consulted, and whenever I modify Nicolaus's translation, the page number of the original notebook immediately follows the notebook number; this pagination is indicated in all standard German editions as well as in the CW translation: (VII 2: 704). Marx's own use of English words is indicated in small capitals.

- 1979. The Letters of Karl Marx. Ed. and trans. Saul K. Padover. Englewood Cliffs, N.J.: Prentice-Hall.

Letters are cited by the sender and addressee, and the day, month, and year they were written: (Marx to Engels, 15 July 1858). Here, too, Marx's own use of English words is indicated in small capitals. 


\section{Translations}

As noted above, I have sometimes modified Nicolaus's translation in quoting from the Grundrisse. All translations from Balzac are my own. All translations of Faust are reprinted from Johann Wolfgang von Goethe, Faust, a Norton Critical Edition, trans. Walter Arndt, ed. Cyrus Hamlin, by permission of W. W. Norton \& Company, Inc. Copyright (C) 1976 by W. W. Norton \& Company, Inc. 